\title{
PENGUATAN KEMAMPUAN SISWA BERPIKIR KREATIF MELALUI MODEL PEMBELAJARAN SNOWBALL THROWING DENGAN MOTIVASI BELAJAR
}

\author{
Intan Ratnasari, Zainul Abidin, Henry Praherdhiono \\ Jurusan Teknologi Pendidikan, Fakultas Ilmu Pendidikan, Universitas Negeri Malang \\ Jalan Semarang 5 Malang 65145 (0341)-574700 \\ Email: intanratnasari74@gmail.com
}

\section{Article History}

Received: 04 Januari 2021, Accepted: 11 Maret 2021, Published: 10 Agustus 2021

\begin{abstract}
Abstrak
Penelitian bertujuan untuk mengetahui pengaruh model pembelajaran Snowball Throwing terhadap kemampuan pebelajar berpikir kreatif pebelajar. Penelitian menggunakan quasy experimental design dengan model sample random sampling. Subjek penelitian ini adalah kelas 8 MTs Raudlatul Ulum Karangploso. Instrumen yang dipakai dalam mengetahui semangat belajar adalah angket sedangkan untuk mengetahui kemampuan pebelajar berpikir kreatif pebelajar memakai tes essay. Untuk hasil penelitian lebih besar nilai dari kelas eksperimen daripada kelas kontrol di segala penilaian, termasuk pada hasil ANAVA dua arah juga memiliki Fhitung yang lebih besar daripada Ftabel. Menunjukkan bahwa model pembelajaran Snowball Throwing dan semangat mempengaruhi kemampuan pebelajar berpikir kreatif pebelajar.
\end{abstract}

Keyword: Model Pembelajaran Snowball Throwing, Motivasi Belajar, Kemampuan Berpikir Kreatif

\begin{abstract}
This study aims to determine the effect of the Snowball throwinglearning model on students' ability to think creatively. This study used a quasy experimental design with a sample random sampling model. The subject of this research was grade 8 MTs Raudlatul Ulum Karangploso. The instrument used in determining the enthusiasm for learning was a questionnaire, while to determine the students' ability to think creatively, students used an essay test. For the results of the study, the value of the experimental class is greater than the control class in all assessments, including the two-way ANOVA results also have Fcount greater than Ftable. Show that the Snowball throwinglearning model and enthusiasm affect the students' ability to think creatively.
\end{abstract}

Keyword: Snowball throwingLearning Model, Learning Motivation, Creative Thinking Skill 


\section{PENDAHULUAN}

Implementasi model pembelajaran mempengaruhi hasil belajar. Model pembelajaran yang hanya bersifat instruksi satu arah, menimbulkan perpermasalahanan pada pebelajar. Perpermasalahanan tersebut adalah pebelajar hanya mampu memahami materi sebatas apa yang disampaikan pendidik (Yang \& He, 2010). Sehingga perlu model pembelajaran, pendidik wajib mengikutsertakan pebelajar secara aktif agar tujuan dari belajar bisa membuahkan hasil yang lebih baik, serta proses belajar mengajar dan penyerapan materi lebih efisien (Praherdhiono et al., 2018).

Berdasarkan hasil penelitian awal di kelas 8 MTs Raudlatul Ulum Karangploso, mereka terlihat masih berpusat pada pendidik dalam belajar. Sehingga pokok bahasan yang diterima pebelajar sebatas penyampaian pendidik. Hal begitu, kemampuan pebelajar berpikir kreatif pebelajar yang masih rendah dapat dipengaruhi. Hasil uji awal menunjukkan sebagian besar pebelajar tidak dapat menjawab pertanyaan. Dari 10 soal, hanya dapat terjawab 3-5 pertanyaan saja. Hal tersebut dikarenakan pebelajar kebanyakan menghafal tanpa memahami secara benar pokok bahasan yang disampaikan. Di sisi lain fungsi pendidik sebagai fasilitator juga memakai model pembelajaran yang seadanya.

Dengan adanya perpermasalahanan tersebut, peneliti memakai model pembelajaran yang semakin inovatif dalam menyampaikan materi. Pemilihan model dalam pembelajaran merupakan hal utama di pembelajaran, pendidik haruslah lebih cermat dalam menetapkan model pembelajaran yang mampu mengkonstruksi kreativitas (Sternberg \& Williams, 1996). Kegiatan belajar selama ini umumnya masih mengacu pada pendidik sehingga pebelajar terlihat bosan dalam mendengarkan penjelasan pendidik, serta semangat belajar pebelajar yang kurang meningkat, selain itu memberi dampak pada kemampuan pebelajar berpikir kreatif yang tidak bisa berkembang. Melihat hal tersebut, maka diperlukan inovasi di pembelajaran dengan memakai model pembelajaran Snowball Throwing. Menurut Puccio dan Mudock (2001), berpikir kreatif berisi aspek keterampilan kognitif pebelajar diantaranya mengidentifikasi permasalahan, menyusun pertanyaan dan melahirkan ide-ide yang berbeda atau ide baru. Hal ini sangat serupa dan sejalan dengan konsep pembelajaran Snowball throwingy akni mengidentifikasi permasalahan secara berkelompok serta membuat pertanyaan secara individu yang mana soal-soal yang dibuat akan dijawab oleh rekannya di kelompok lain, begitupun sebaliknya.

Berdasarkan kerangka permasalahan diatas, maka peneliti menentukan model pembelajaran Snowball throwing di pembelajaran karena pembelajaran sering berpusat pada pebelajar, sehingga fungsi pendidik disini hanyalah mengarahkan, mesemangat dan memfasilitasi dalam memecahkan permasalahan di pembelajaran ini. Oleh sebab itu, penelitian bertujuan untuk melihat apakah terdapat pengaruh model Snowball throwing serta semangat belajar terhadap kemampuan pebelajar berpikir kreatif pebelajar kelas 8 MTs Raudlatul Ulum Karangploso.

Menurut Ani Rosidah (2017) model Snowball throwing adalah model pembelajaran yang diawali dengan pembentukan kelompok dan memilih kepala kelompok yang setiap kelompok diberikan tugas oleh pendidik, selanjutnya pebelajar menciptakan pertanyaan berbentuk bola selanjutnya dilempar kepada pebelajar lainnya dan pebelajar yang menerima bola kertas tersebut menjawab pertanyaan yang diberikan. Hal ini memperlihatkan bahwa model Snowball throwing bisa melatih kekompakan pebelajar dalam berkelompok, juga membuat pebelajar tidak cepat bosan melalui model pembelajaran yang disampaikan dari guru.

Pemanfaatan model Snowball throwing merupakan sarana untuk tercapainya kualitas pendidikan. Pengertian Snowball throwing adalah model yang menyaajikan pengalaman kepada pebelajar dengan pembelajaran terpadu memanfaatkan proses yang berkaitan dalam situasi serta bidang komunikasi alamiah maupun sosial, alam, angka serta lingkungan pergaulan (Alfira, 2019; Ginting, 2017; Khairani et al., 2019). 
Hal lain dalam pembelajaran yang berkualitas juga bergantung pada semangat belajar pebelajar. Tinggi rendahnya usaha yang dilaksanakan seorang dalam tercapainya tujuan akan diputuskan oleh tinggi rendahnya semangat yang dipunyai orang itu (Lumsden, 1994). Pembelajaran yang mempunyai semangat tinggi didukung melalui pembelajaran yang dapat mengantarkan pada suatu pencapaian target belajar yang berhasil. Tujuan belajar bisa terukur dengan mengubah sikap dan kemampuan yang dipunyai pebelajar melalui aktivitas belajar.

Cara mengetahui kemampuan pebelajar melalui berpikir kreatif di kelas 8 MTs Raudlatul Ulum, selain menggunakan model Snowball Throwing, peneliti juga meninjau dari segi semangat pebelajar belajar. Dengan adanya semangat, pebelajar mampu belajar lebih giat, rajin serta mempunyai fokus penuh dalam pembelajaran. Semangat belajar yang dipunyai pebelajar dalam semua aktifitas pembelajaran berperan penting dalam menaikkan prestasi belajar pebelajar (Amrein \& Berliner, 2003). Pebelajar yang mempunyai semangat tinggi dalam belajar dapat menghasilkan nilai yang memuaskan, artinya lebih tinggi semangatnya, semakin banyak usaha serta upaya yang dilaksanakan, maka semakin tinggi pencapaian hasil belajar.

Keutamaan berpikir pada manusia yakni untuk menspesifikasikan permasalahan, mencari solusi permasalahan, mencari pengetahuan dan memberikan sebuah keputusan. Proses berpikir yakni tahapan serta cara dasar yang diproses akal manusia dalam mengolah serta melakukan pengetahuan yang diperolehnya untuk mendapatkan kebenaran, (Lau, 2011) menyatakan, muara berpikir terdapat pada berpikir secara kritis serta berpikir dengan kreatif. Cara pebelajar berpikir bisa terlihat ketika pebelajar menangani keadaan yang tidak biasa dalam bentuk permasalahan disertai dengan kemauan untuk menyelesaikannya (Mairing, 2017).

Memecahkan permasalahan, memahami tujuan permasalahan, mencari beberapa solusi, menentukan cara tepat untuk digunakan, serta diterapkan solusi yang ditentukan merupakan sekumpulan aktivitas mental dalam berpikir (Parnawi, 2019). Pebelajar yang menawarkan solusi yang kreatif melalui berpikir kreatif (Leikin \& Pitta-Pantazi, 2013). Beberapa penelitian yang membahas kreativitas seseorang berdasarkan hasil pemecahan permasalahan yang mencakup tiga aspek kreatif, menjelajahi proses berpikir kreatif dengan menekankan pentingnya dalam menentukan tugas yang tepat untuk dipertimbangkan sebagai faktor yang dapat mendukung kategori jawaban kreatif untuk memperhatikan proses mental yang menjadi dasar masukan (Yerushalmy, 2009). Berkenaan adanya proses berpikir kreatif, beberapa ahli menyampaikan tahapan untuk mendeskripsikan proses tersebut. Wallas (1926) yang didukung oleh Jovanovich (1976) menyarankan model dalam 4 tahap yakni (1) Keluwesan, yaitu menggabungkan informasi yang signifikan dengan permasalahan, merumuskan permasalahan serta menciptakan upaya awal untuk memecahkannya; (2) Elaborasi, yaitu masa dimana upaya yang dikerjakan secara langsung dalam memecahkan permasalahan secara rinci; (3) Orisinalitas, yaitu ide asli memperoleh suatu pandangan atau rencana pemecahan dari permasalahan tersebut; (4) Kelancaran, melaksanakan dan menguji ide atau pemahaman yang didapat dan menciptakan solusi. Sternberg dan Williams (1996) mengemukakan bahwa kreativitas adalah titik temu antara tiga atribut psikologi, yaitu intelegensi, gaya kognitif, dan kepribadian atau semangat.

\section{METODE}

Desain penelitian yang dipakai yakni quasi experimental design dengan model sample random sampling. Peneliti memilih simple random sampling karena kelas eksperimen dan kelas kontrol ditentukan acak tanpa melihat tingkatan pada populasi tersebut.

Populasi penelitian ini yakni pebelajar kelas 8 MTs Raudlatul Ulum berjumlah 75 pebelajar terbagi menjadi 3.Untuk subjek penelitian, peneliti mengambil subjek kelas 8A 25 pebelajar dengan pebelajar laki-laki sebanyak 10 pebelajar serta pebelajar perempuan sebanyak 15 pebelajar sedangkan kelas 8B 25 pebelajar dengan laki-laki 13 serta pebelajar perempuan sebanyak 12 pebelajar. 
Instrumen yang dipakai di penelitian yakn angket dan soal tes essay. Instrumen angket dipakai untuk mendapati semangat belajar pebelajar kelas eksperimen serta kelas kontrol, dengan memakai indikator angket motivasi belajar pendapat dari Sardiman A. M. (2011) yakni rajin belajar, ulet dalam menangani kesukaran, menampakkan minat belajar, senang belajar mandiri, mudah bosan bila diberi tugas rutin, bisa mempertahankan opini, tidak mudah meninggalkan sesuatu yang diyakini, serta senang memburu dan memecahkan permasalahan soal-soal.

- Sedangkan instrumen tes menggunakan soal pretest dan posttest berbentuk uraian atau essay dengan melihat indikator kemampuan pebelajar berpikir kreatif yaitu kelancaran, keluwesan, orisinil dan elaborasi. Hal ini dilaksanakan untuk melihat kemampuan pebelajar berpikir kreatif sebelum dan sesudah diberikan model Snowball Throwing.

Uji homogenitas dipakai untuk melihat apakah kelas eksperimen serta kelas kontrol yang dipakai di penelitian mempunyai bentuk yang homogen atau tidak. Taraf hasil signifikansi uji homogenitas yaitu $\alpha=0,05$. Apabila Sig. $>\alpha$ maka data dikatakan homogen. Jika Sig. $<\alpha$ maka data dikatakan tidak homogen.

Uji normalitas dipakai untuk melihat apakah sebaran data normal atau tidak. Karena jumlah responden di penelitian ini berjumlah 50 responden, maka peneliti memakai Shapiro-Wilk dengan ketetapan responden $<50$ serta memakai Kolmogorov-Smirnov dengan ketetapan responden $>50$. Uji normalitas mempunyai kriteria pengujian, yakni taraf signifikansi $\alpha=0,05$. Apabila Sig. $>\alpha$ maka sebaran data normal, sedangkan jika Sig. $<\alpha$ maka sebaran data tidak normal.

Uji hipotesis yang dipakai yakni uji Independent Simple T-Test serta uji ANAVA dua arah. Untuk mengujikan apa ada perbedaan nilai kemampuan pebelajar berpikir kreatif yang signifikan antara yang memakai Snowball throwing dan memakai pembelajaran konvensional maka hipotesis yang digunakan yakni uji Independent Sample T-Test dengan kriteria pengujian, yakni taraf signifikansi $\alpha=0,05$. Jika Sig. $<\alpha$ maka data H0 ditolak dan Ha diterima, sedangkan Sig. $>\alpha$ maka data H0 diterima dan Ha ditolak. Sedangkan untuk melihat ada pengaruh yang signifikan antara model Snowball throwingserta motivasi belajar terhadap kemampuan pebelajar berpikir kreatif, menggunakan uji hipotesis ANAVA dua arah. Untuk mengujikan hipotesis yang dikemukakan itu diterima atau ditolak yakni melihat nilai $\mathrm{F}$ dan Signifikansi (Sig.). Ketetapan penerimaan atau penolakan terjadi apabila nilai Fhitung $>$ Ftabel dan Signifikansi (Sig.) $<0,05(\alpha)$, maka H0 ditolak dan Ha diterima. Apabila nilai Fhitung $<$ Ftabel dan Signifikansi (Sig.) $>0,05(\alpha)$, maka H0 diterima dan Ha ditolak.

\section{HASIL}

Hasil angket kelas eksperimen serta kelas kontrol pada penelitian yang sudah dilaksanakan yaitu nilai rata-rata angket di kelas eksperimen sejumlah 120,80 sedangkan di kelas kontrol sebesar 114,00. Artinya hasil angket kelas eksperimen lebih tinggi dibandingkan dengan kelas kontrol.

Nilai rata-rata pretest pada kelas eksperimen sebesar 56,60 sedangkan kelas kontrol sebesar 49,20. Artinya pretest kelas eksperimen lebih tinggi dibandingkan dengan kelas kontrol, sedangkan nilai rata-rata posttest pada kelas eksperimen sebesar 82,60 dan kelas kontrol sebesar 73,20. Berarti hasil posttest kelas eksperimen lebih tinggi apabila dibandingkan dengan kelas kontrol.

Dari pengujian homogenitas ditunjukkan nilai signifikansi (Sig.) variabel kemampuan pebelajar berpikir kreatif pada pebelajar kelas 8A serta kelas 8B yakni sebesar 0,092. Karena nilai Sig. 0,092 > 0,05 , maka kesimpulan dasar pengambilan keputusan uji homogenitas yakni varians data kemampuan pebelajar berpikir kreatif pada pebelajar kelas 8A serta kelas 8B yaitu sama atau homogen.

Hasil dari pengujian normalitas bahwa nilai signifikansi uji Kolmogorov-Smirnov sebesar 0,200 lebih besar dari 0,05, sehingga berdasarkan uji normalitas Kolmogorov-Smirnov diatas, berkesimpulan 
sebasaran data normal. Sedangkan nilai signifikansi pada uji Shapiro-Wilk sebesar 0,560 lebih besar dari 0,05 , sehingga berdasarkan uji normalitas Shapiro-Wilk diatas, bisa disimpulkan sebaran data normal.

Pada hasil dari uji hipotesis memakai Independent Samples T Test dengan nilai Signifikansi (2tailed) yakni 0,002 <0,05. Bisa disimpulkan terdapat perbedaan hasil dari kelas eksperimen dan kelas kontrol antara yang memakai model Snowball throwingdengan yang memakai model konvensional di kelas 8 MTs Raudlatul Ulum Karangploso.

Hasil dari uji hipotesis menggunakan ANAVA dua arah pada penelitian ini dapat dilihat pada tabel 1.

\section{Tabel 1 Uji ANAVA Dua Arah}

\begin{tabular}{|c|c|c|c|c|c|}
\hline \multicolumn{6}{|c|}{$\begin{array}{l}\text { Tests of Between-Subjects Effects } \\
\text { Dependent Variable: HasilKemampuanBerpikirKreatif }\end{array}$} \\
\hline Source & Type III Sum of Squares & Df & Mean Square & $\mathrm{F}$ & Sig. \\
\hline Corrected Model & $4717.972^{a}$ & 5 & 943.594 & 32.588 & .000 \\
\hline Intercept & 253758.574 & 1 & 253758.574 & 8763.841 & .000 \\
\hline Model & 1168.784 & 1 & 1168.784 & 40.365 & .000 \\
\hline Semangat & 3467.143 & 2 & 1733.571 & 59.871 & .000 \\
\hline Model * Semangat & 446.570 & 2 & 223.285 & 7.711 & .001 \\
\hline Error & 1274.028 & 44 & 28.955 & & \\
\hline Total & 309412.500 & 50 & & & \\
\hline Corrected Total & 5992.000 & 49 & & & \\
\hline
\end{tabular}

a. R Squared $=.787$ (Adjusted R Squared $=.763$ )

Berdasarkan pada kolom Model, didapat nilai Fhitung $(40,365)>$ Ftabel $(4,03)$ dan taraf nilai Signifikansi (Sig.) 0,000 < 0,05, sehingga dapat disimpulkan H0 ditolak dan Ha diterima, artinya ada pengaruh model Snowball throwingterhadap kemampuan pebelajar berpikir kreatif. Lalu di kolom motivasi, diperoleh nilai Fhitung $(59,871)>$ Ftabel $(3,18)$ dan taraf nilai Signifikansi (Sig.) 0,000 < 0,05, maka dari itu dapat disimpulkan H0 ditolak dan Ha diterima, artinya ada pengaruh semangat belajar terhadap kemampuan pebelajar berpikir kreatif. Selanjutnya dikolom Model*Semangat diperoleh nilai Fhitung $(7,711)>$ Ftabel $(3,18)$ dan taraf nilai Signifikansi (Sig.) 0,001 < 0,05, sehingga bisa disimpulkan H0 ditolak dan Ha diterima, artinya ada pengaruh model Snowball throwingdan motivasi belajar terhadap kemampuan pebelajar berpikir kreatif.

Secara rinci didapat dari rerata hasil belajar setiap kelas yaitu : (1) kelas eksperimen dengan pelaksanaan model Snowball throwingterperoleh 12 pebelajar mempunyai tingkat semangat tinggi, 4 pebelajar mempunyai semangat sedang, 9 pebelajar mempunyai semangat rendah serta rerata hasil kemampuan pebelajar berpikir kreatif yang semangatnya tinggi adalah 88,958, rerata hasil kemampuan pebelajar berpikir kreatif yang semangatnya sedang adalah 79,375 sedangkan rerata hasil kemampuan pebelajar berpikir kreatif yang semangatnya rendah adalah 75,556. (2) kelas kontrol dengan pelaksanaan model konvensional terperoleh 10 pebelajar mempunyai tingkat semangat tinggi, 9 pebelajar mempunyai semangat sedang, 6 pebelajar mempunyai semangat rendah dan rerata hasil kemampuan pebelajar berpikir kreatif yang semangatnya tinggi adalah 82,750 , rerata hasil kemampuan pebelajar berpikir kreatif yang semangatnya sedang adalah 73,889 sedangkan rerata hasil kemampuan pebelajar berpikir kreatif yang semangatnya rendah adalah 56,250. Sehingga pebelajar yang belajar dengan model Snowball throwinghasil kemampuan pebelajar berpikir kreatifnya lebih memuaskan dibandingkan pebelajar yang belajar dengan model konvensional, serta pebelajar yang tingkat semangatnya tinggi hasil kemampuan pebelajar berpikir kreatifnya lebih baik apabila dibandingkan dengan pebelajar yang tingkat semangatnya rendah. Hasil analisis data taraf signifikansi $5 \%$ menentukan nilai Sig. Model pembelajaran dan tingkat semangat yaitu sig. 0,001<0,05 dan nilai Fhitung $=7,711>$ Ftabel $=3,18$. 


\section{PEMBAHASAN}

Perbedaan nilai di kelas eksperimen dan kelas kontrol terjadi dikarenakan pebelajar yang belajar dengan menerapkan model Snowball throwinglebih aktif , hidup dan antusias dibandingkan pebelajar yang belajar dengan model konvensional. Ada penelitian yang memperlihatkan bahwa pebelajar sangat antusias dalam proses pembelajaran yaitu dalam menyimak penjelasan guru, dan berdiskusi dalam kelompok membangun pertanyaan (Adhiatmika et al., 2017; Alfira, 2019; Alwi \& Hamimah, 2018; Ginting, 2017). Pebelajar di kelas eksperimen dibiasakan aktif ketika berdiskusi dengan materi yang disampaikan, sedangkan pendidik hanya membimbing secara perlahan. Di kelas kontrol pendidiklah yang lebih berperan serta dalam pembelajaran, sedangkan pebelajar hanya mengamati, mendengarkan dan menulis apa yang dikemukakan pedidik.

Hasil dari ANAVA dua arah memperlihatkan bahwa ada pengaruh model Snowball throwingterhadap kemampuan pebelajar berpikir kreatif. Sehingga pebelajar yang diberi model Snowball throwingbisa mengbuahkan kemampuan pebelajar berpikir kreatif yang lebih baik daripada kelas yang tidak diberi perlakuan (konvensional).

Snowball throwingadalah model pembelajaran aktif, yang mana implementasinya banyak melibatkan pebelajar. Peran pendidik sebagai pemberi acuan awal tentang topik pembelajaran serta penertiban alur pembelajaran. Dalam Snowball throwingpendidik membentuk kelompok lalu diberi tugas menciptakan sebuah pertanyaan tentang suatu materi tertentu, selanjutnya masing-masing pebelajar dalam kelompok membuat pertanyaan yang dibentuk bola, lalu dilempar ke pebelajar satu sama lain, yang memperoleh pertanyaan wajib menjawabnya. Melalui model Snowball throwingpembelajaran bisa memacu serta mengembangkan keterampilan berpikir kreatif pebelajar. Belajar berkelompok bisa melatih pebelajar untuk berbagi wawasan, pengalaman, tugas, dan tanggung jawab (Shoimin, 2011).

Kreatif dalam memecahkan permasalahan membutuhkan sebuah faktor kreativitas pada pebelajar dalam mencari solusi, pada umumnya saat pebelajar mendapatkan suatu perpermasalaha, akan mengalami kegelisahan dan risau. Maka dari itu adanya suatu permasalahan perlu dipecahkan atau menyelesaikan, supaya tidak diperoleh lagi permasalahan itu sehingga tidak mengganggu. Semua pembelajaran adalah pemecahan permasalahan, sedang pemecahan permasalahan adalah sejumlah tugas yang cukup kompleks untuk diidentifikasi sebagai suatu nama lain (Dewi et al., 2017; Kim \& Hannafin, 2011; Sulton \& Susilo, 2018). Oleh sebab itu model Snowball throwingdiharapkan mampu memantik pebelajar untuk berpikir kreatif serta mampu mengidentifikasikan permasalahan secara tuntas.

Keberhasilan kreativitas terwujud karena persimpangan (intersection) dari keterampilan anak di bidang tertentu (domain skills), keterampilan berpikir serta bekerja kreatif, dan semangat intrinsik (Amabile, 1996, 1998, 2012). Persimpangan kreativitas disebut sebagai teori persimpangan kreativitas (creativity intersection)

Sedangkan, perbedaan yang ada pada hasil data kelas eksperimen serta kelas kontrol, memperlihatkan nilai kelas eksperimen lebih tinggi semangat belajarnya apabila dibandingkan kelas kontrol, dikarenakan di kelas eksperimen banyak pebelajar yang cenderung mempunyai semangat tinggi yang disebabkan dari dalam dirinya sendiri atau dari penggerak yang membuat pebelajar tersemangat untuk belajar, dibandingkan kelas kontrol yang pebelajarnya tidak banyak mempunyai semangat belajar dikarenakan mungkin kurang menggerakkan perasaannya untuk belajar. Untuk hasil ANAVA dua arah yang dilakukan, mempunyai kesimpulan bahwa semangat belajar bisa mempengaruhi hasil kemampuan pebelajar berpikir kreatif.

Proses pembelajaran motivasi menjadi aspek dinamis yang sangat penting. Tidak jarang terjadi pebelajar yang kurang berprestasi bukan disebabkan oleh kemampuannya yang kurang, melainkan 
tidak adanya semangat untuk terus belajar sehingga ia pun tidak berusaha untuk mengarahkan semua kemampuannya yang dipunyai (Sanjaya, 2008).

Pada aktivitas belajar, semangat bisa dikatakan sebagai keseluruhan daya penggerak yang ada dalam diri pebelajar itu sendiri yang bisa menimbulkan adanya kegiatan belajar, yang menjamin keberlangsungan dari aktivitas belajar, sehingga tujuan yang akan dicapai oleh subjek belajar dapat terwujud (Sardiman, 2004), motivasi merupakan perubahan energi di dalam diri pribadi seseorang yang ditandai adanya afektif (perasaan) yang timbul serta reaksi agar bisa mencapai tujuan (Mc Donald dalam Kompri, 2016). Semangat belajar bisa mendorong kepada seseorang untuk melakukan kegiatan belajar. Adanya semangat belajar, maka seseorang akan bisa melakukan berbagai macam aktivitas yang ada, terutama aktivitas belajar sehingga tujuan awal belajar dapat terwujud.

Pentingnya semangat saat belajar yakni sebagai berikut: "Semangat itu penting adanya, bahkan meski tanpa kesepakatan yang ditentukan tentang definisi konsep itu. Apabila diperoleh dua anak yang mempunyai kecakapan sama serta memberi peluang dan keadaan yang sama untuk mewujudkan tujuan, kinerja juga hasil yang akan dicapai oleh anak yang tersemangat akan lebih baik apabila dibandingkan dengan anak yang kurang atau bahkan tidak tersemangat. Secara sederhananya dapat dikatakan bahwa anak tidak mempunyai semangat belajar, maka tidak akan terjadi aktivitas belajar apapun pada diri anak itu. Walaupun begitu, kadang-kadang itu menjadi sebuah permasalahan, dikarenakan semangat bukanlah suatu keadaan. Apabila semangat pebelajar anak itu rendah, umumnya diasumsikan dari prestasi pebelajar yang bersangkutan rendah" (Rifa'i dan Anni ,2009).

Pebelajar dikatakan tersemangat apabila sering bertanya kepada pendidik atau kepada temantemannya, berkenan mengerjakan tugas yang diberikan pendidik, bisa menjawab pertanyaan, senang hati diberi tugas belajar dan sebagainya. Semangat bisa jadi daya gerak yang menjamin adanya keberlangsungan aktivitas belajar serta memberikan petunjuk pada aktivitas belajar sehingga tujuan yang diinginkan dapat terpenuhi dengan baik (Herlina, 2016).

Adanya semangat yang baik ketika belajar akan menampakkan hasil yang baik, dengan adanya usaha yang tekun, rajin, ulet dan yang utama didasari oleh adanya semangat, maka seseorang yang belajar itu akan bisa melahirkan prestasi yang baik. Intensitas semangat seorang pebelajar akan sangat menetapkan tingkat-tingkat pencapaian pada prestasi belajarnya. Berdasarkan temuan tersebut bisa disimpulakn bahwa pebelajar yang mempunyai semangat tinggi, lebih baik kemampuan pebelajar berpikir kreatifnya daripada pebelajar yang mepunyai semangat rendah.

Pada hasil ANAVA dua arah diperoleh nilai signifikansi model pembelajaran serta semangat yang lebih kecil dari nilai signifikansi sehingga bisa dikatakan bahwa pebelajar yang belajar dengan memanfaatkan model Snowball throwinghasil kemampuan pebelajar berpikir kreatif lebih baik jika dibandingkan pebelajar yang belajarnya dengan model konvensional, dan pebelajar yang tingkat semangatnya tinggi hasil kemampuan pebelajar berpikir kreatifnya lebih baik dibandingkan dengan pebelajar yang tingkat semangatnya rendah.

Pada penelitian (Fauziah, 2019), penelitian dengan model Snowball throwingtelah terbukti bisa memberikan dampak kemampuan pebelajar berpikir kreatif pebelajar. pelaksanaan Snowball throwingdikatakan berfungsi mempengaruhi karena perspektif yang ada mampu menghidupkan kemampuan pebelajar berpikir kreatif. Kemudian pada penelitian (Tina, 2020) semangat belajar mempengaruhi kemampuan pebelajar berpikir kreatif yang dibuktikan dengan banyaknya semangat yang ada pada diri pebelajar sehingga kemampuan pebelajar berpikir kreatifnya pun juga dapat dipengaruhi.

Berdasarkan temuan tersebut dapat disimpulkan bahwa model Snowball throwingmempunyai pengaruh yang signifikan kepada hasil kemampuan pebelajar berpikir kreatif , begitu pula pebelajar yang mempunyai semangat tinggi akan cenderung mempunyai kemampuan pebelajar berpikir kreatif 
yang lebih baik daripada pebelajar yang mempunyai semangat rendah, artinya semangat belajar juga berpengaruh pada kemampuan pebelajar berpikir kreatif.

\section{SIMPULAN}

Berdasarkan hasil dan pembahasan yang telah dijabarkan, mengenai pengaruh model Snowball throwingserta semangat belajar terhadap kemampuan pebelajar berpikir kreatif kelas 8 MTs Raudlatul Ulum Karangploso, melahirkan kesimpulan yakni pebelajar yang diberi model Snowball throwing lebih tinggi nilai kemampuan pebelajar berpikir kreatifnya yang diperoleh daripada pebelajar yang hanya diberi model konvensional, begitu pula pebelajar yang mempunyai semangat tinggi lebih baik daripada pebelajar yang bersemangat rendah sehingga mempengaruhi terhadap kemampuan pebelajar berpikir kreatifnya. Dengan demikian, model Snowball throwing dan semangat belajar berpengaruh terhadap kemampuan pebelajar berpikir kreatif.

\section{DAFTAR RUJUKAN}

Adhiatmika, M., Agustini, K., \& ... (2017). Pengaruh Model Pembelajaran Kooperatif Tipe Snowball throwingTerhadap Hasil Belajar Pebelajar Pada Mata Pelajaran TIK Kelas VIII SMP Negeri 5 Tejakula. KARMAPATI, Vol. 6, No. 1

Alfira, N. (2019). Hubungan model pembelajaran Snowball throwingterhadap hasil belajar matematika pebelajar. Journal of science and social ..., Vol. 2, No. 1

Alwi, E., \& Hamimah, H. (2018). Peningkatan Hasil Belajar Pebelajar Dalam Pembelajaran Ips Dengan Model Snowball Throwing. E-Journal Pembelajaran Inovasi, Jurnal ..., Vol. 6, No. 2

Amabile, T. M. (1996). Creativity and innovation in organizations.

Amabile, T. M. (1998). How to kill creativity (Vol. 87). Harvard Business School Publishing Boston, MA.

Amabile, T. M. (2012). Componential theory of creativity. Harvard Business School, 12(96), 1-10.

Amrein, A. L., \& Berliner, D. (2003). Student motivation and learning. NJ USA: HW Wilson Co.

Boden, M. A. (2001). Creativity and knowledge. Creativity in Education, 95-102.

Dewi, I., Poedjiastoeti, S., \& ... (2017). Elsii learning model based local wisdom to improve students' problem solving skills and scientific communication. International Journal of ..., Vol. 5 No. 1

Emda, A. (2018). Kedudukan semangat belajar pebelajar dalam pembelajaran. Lantanida Journal, 5(2), $172-182$.

Fauziah. Nur. H. (2019). Pengaruh Penggunaan Model Pembelajaran Snowball throwingTerhadap Kemampuan pebelajar berpikir kreatif Pebelajar Kelas III MIN 7 Tulungagung. IAIN Tulungagung, Tuluagung, Indonesia

Ginting, M. (2017). Snowball throwingLearning Model Implementation in order to Increase Student Civic Education Learning Outcomes. Researchers World, Query, Vol. 8, Iss. 3,120-125

Hamalik, O. (2007). Dasar-dasar pengembangan kurikulum. Bandung: PT. Remaja Rosdakarya.

Jovanovich, H. B. (1976). GRAHAM WALLAS Stages in the Creative Process. The Creativity Question, 69.

Khairani, E., Ristiono, R., Helendra, H., \& ... (2019). ... Effect of the application of the Cooperative Learning Model Type Snowball throwingAgainst an increase in the activity of learning to the learners on subjects Science .... Atrium Pendidikan ..., Vol. 4, No. 1

Kim, M. C., \& Hannafin, M. J. (2011). Scaffolding problem solving in technology-enhanced learning environments (TELEs): Bridging research and theory with practice. Computers \& Education, 56(2), 403-417.

Lau, J. Y. (2011). An introduction to critical thinking and creativity: Think more, think better. John Wiley \& Sons. 
Leikin, R., \& Pitta-Pantazi, D. (2013). Creativity and mathematics education: The state of the art. ZDM, 45(2), 159-166.

Lumsden, L. S. (1994). Student Motivation. Research Roundup, 10(3), n3.

Mairing, J. P. (2017). Thinking Process of Naive Problem Solvers to Solve Mathematical Problems. International Education Studies, 10(1), 1-11.

Parnawi, A. (2019). Psikologi Belajar. Deepublish.

Piirto, J. (2011). Creativity for 21st century skills. In Creativity for 21st Century Skills (pp. 1-12). Springer.

Praherdhiono, H., Abidin, Z., Adi, E. P., Prihatmoko, Y., \& Soepriyanto, Y. (2018). Learning Design for Strengthening of Learner Self-Concept. International Conference on Education and Technology (ICET 2018).

Rachmawati, R. (2018). Analisis Keterkaitan Standar Kompetensi Lulusan (SKL), Kompetensi Inti (KI), dan Kompetensi Dasar (KD) dalam Implementasi Kurikulum 2013. Tatar Pasundan: Jurnal Diklat Keagamaan, 12(34), 231-239.

Rifa'i, A., \& Anni, C. T. (2009). Psikologi pendidikan. Semarang: Unnes.

Sandi, I. K., Suwatra, I. I. W., \& Widiana, I. W. (2014). Pengaruh Model Pembelajaran Snowball throwing Terhadap Hasil Belajar IPA Dengan Kovariabel Kemampuan pebelajar berpikir kreatif Pebelajar Kelas IV SD. Mimbar PGSD Undiksha, 2(1).

Sanjaya, W. (2008). Kurikulum Dan Pembelajaran (Teori \& Praktek KTSP). Kencana.

Sardiman, A. M. (2004). Interaksi \& semangat belajar mengajar. Rajagrafindo persada (rajawali pers).

Shoimin, A. (68). Model pembelajaran inovatif dalam kurikulum 2013. Yogyakarta: Ar-Ruzz Media, 210.

Sternberg, R. J., \& Williams, W. M. (1996). How to develop student creativity. ASCD.

Sulton, E. P. A., \& Susilo, H. (2018). Curriculum Model of Capability Development through Transdisciplinary Courses System.

Tina. WO. (2020). Pengaruh Semangat Belajar Pebelajar Terhadap Berpikir Kreatif Pada Materi Aplikasi Operasi Himpunan Kelas VII SMP Muhammadiyah Ambon, Ambon, Indonesia.

Wallas, G. (1926). The art of thought.

Yang, E.-H., \& He, D.-K. (2010). Interactive encoding and decoding for one way learning: Near lossless recovery with side information at the decoder. IEEE Transactions on Information Theory, 56(4), 1808-1824.

Yerushalmy, M. (2009). Educational technology and curricular design: Promoting mathematical creativity for all students. In Creativity in mathematics and the education of gifted students (pp. 101-113). Brill Sense. 